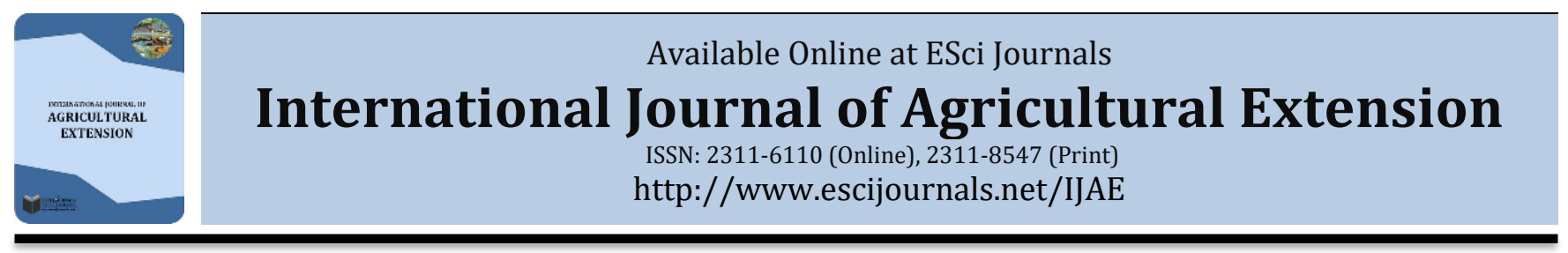

\title{
SNAPSHOT OF PUBLIC AND PRIVATE AGRICULTURAL EXTENSION SERVICES IN BALOCHISTAN: AN APPROACHES FOR THE DISCIPLINE
}

\author{
aAhmed A. Mengal*, bFateh M. Baloch, cAkhtar A. Siddique, dZia Ur Rehman \\ ${ }^{a}$ Agribusiness Directorate, Agriculture Research Institute, (ARI), Quetta, Balochistan, Pakistan. \\ ${ }^{b}$ Livestock Research Institute (PARC) Turbat Balochistan, Pakistan. \\ c Agriculture Extension Wing, Hyderabad, Sindh, Pakistan. \\ d Pakistan Institute of Prosthetic and Orthotics Sciences (PIPOS) Hyatabad Peshawar, Khyber Pakhtunkhwa, Pakistan.
}

\section{A B S T R A C T}

Present study was examined the perceived limiting factors within agriculture extension system in Balochistan, Pakistan. One hundred (100) Extension Field Staff (EFS) were selected by using simple random sampling technique for the present study form the public and private extension services. A research instrument based on 5-point Likert scale was used so as to acquire the information from the EFS. Nonparametric Statistics i.e. Mann and Whitney's U Test (1947) as appropriate between dual groups was calculated so as to find out the relationships between variables that have significance differences at $\mathrm{p}<.005$. The results depicted that significant differences were found 4 out of 10 categories regarding the extension teaching methods therefore, null hypothesis 1 was rejected. Further, ten (10) statements observed to found statistical non-significant at all regarding sources of information. Hence, the HO2 was accepted in the favour of alternate hypothesis. Based on aforementioned outcomes following recommendations putforward. Dissemination of improved and useful information's to the farmers are the vivid encouragement tools and energizer trends about crop production dynamics in this regard, it is therefore suggested that, extension teaching methods (individuals and groups contact methods) such as demonstration plots, farm visits, home visits, uses audiovisual media, seminar, campaigns, workshops, trainings should be arranged at districts and province level so that activate the entire agricultural extension system. Active crop maximization approach should be implemented in preliminary stages in order to increases the income generations and livelihood options of the farmers.

Keywords: Balochistan, linear stimulation, snapshot agricultural extension system, technology transfer.

\section{INTRODUCTION}

Agriculture sector remains lifeline pillar of Pakistan's economy contributing $19.8 \%$ to national Gross Domestic Product (GDP) and offering $42.3 \%$ of the labor-forces. Agriculture stays leading source of export-earnings through provisions of raw materials to local agro-based industries such as textile, sugar, cotton and so on. Agriculture sector not only the foremost source of revenues generating for the rustic masses, but also contribute 70 percent of livelihood opportunities rotated around the agriculture and other allied agriculture activities (GoP, 2016). The agriculture activities reflect the positive impact in the socio-economic ailments and

* Corresponding Author:

Email: ahmedagric@gmail.com

(C) 2018 ESci Journals Publishing. All rights reserved. livelihood options of the resident of rural masses and eliminate to help the poverty at grass root level (GoP, 2016). Transfer of cutting-edge agricultural know-hows contributes towards enriching the agrarian production (Javed et al., 2010). Without effective transfer of technology, the dimension of extension services was bleak, null and void. The technology transfer was the indispensable, part and parcel trait in the agriculture extension arrangement. Effective linkages among the dynamic sectors are the lingered a massive task target of the extension system (Qamar, 2005).

Despite the unique sort of agro-climatic zones' beginning from coastal belt to barren deserts and fertile plains to mountainous the agriculture sector still plays a domineering role and economy backbone of vast majority of the populaces with the term of income 
generation sources. Agriculture sector get used to working at province are being exercised in a special and particular method as comparison to other provinces of the country due to its unique strategic location, landscape features, remote areas, peculiar socioeconomic settings of the farmers, farming types (minor pockets/valleys of distant areas), scattered nature of settlements, small agriculture land holdings size and many other off-putting factors.

The encyclopaedic and rigorous progress of agriculture is concern development in the exploration effort, which is in liable for the constant evolution of innovations, but all these assessment efforts are not at all practices unless these foci themes of advancement are dispersed among their ultimate users i.e. farmers. This expertise work can expertly be executed through the effective and efficient extension advisory services so that motivate to mobilize the intended farmers to discard/ abandon the outmoded and traditional farming system and take on the latest agriculture technology.

Frequent communication and link (triangular relationship) among productive sectors (researchextension-farmers) are although non-existent. Specific informal liaison exists on the basis of discussions at different seminars, conferences and field days. Nonetheless, these are situated unplanned, unstructured and performed wholly on an ad-hoc ground at province level. They did not epitomize a potent mechanism for communicate and suitable planning and assessment tactics. Whilst because of these de-linked phenomena, the research institute results are usually not being appropriately transmitted to the farming group. In order to accelerate the socio-economic circumstance and deliverance of useful agriculture information and knowhow to the farming communities' door step, the present structure (Agriculture \& Cooperatives Department Government of Balochistan) was chalked out the aggressive footstep and approaches to conduct/ arrange the field days, demonstration plots and seminars at district level through the Extension Wing and Research Institute experts regularly. But unfortunately, efforts of these initiatives have not been rewarding due to lack of proper monitoring system, dearth operational mechanism, weak HRD section and limited available resources (Mengal et al., 2014).

Rationale of the study: The performance of agriculture extension services has consistently been controversial and a dilemma of debate on global milieu. The fundamental function of the agriculture extension services is to educate, train, stimulate, facilitate and change the attitude of the farmers and suggestions the sophisticated agriculture technology suggestions for the intended beneficiaries. Lamentably, the extension services have in most cases been evaluated through nonauthorities and then too had been perplexed beyond their mandate and scope. Different agriculture extension approaches, and techniques are working for the improvement of farmer's income and rural development initiatives in Balochistan. Both public and private extension services rendered diverse advisory services and extension approaches for the grower, for instance, traditional extension system, modified Training \& Visit (T\&V) system, participatory system, integrated area development system and so forth. These techniques sort-out no longer fit-well into the current requirements of more revolutionary, intensive and integrated agriculture (Mengal et al., 2012). The flaw lies in its horizontal axis and vertical axis via of associations and operational mechanism comprising the methodology used for transfer of technology. There was deficiency of mechanism for instant credentials of emerging issues and quick response the technology needs of the farmers. At presently the agricultural extension delivery system has binary categorizations working instantaneously in the province of Balochistan: 1) traditional extension system and 2) modified $\mathrm{T} \& \mathrm{~V}$ system. At present the agriculture system relies and based on Kharif and Rabi annual programs and fixing targets. Generally, the agriculture extension system was operated a hierarchical, linear, elaborate bureaucratic and topdown approach/ style at province level (Mengal et al., 2014; Mengal et al., 2012) and virtually no exertions are finished to need-base development which did not constitute the farmers' actual problems in this connection, the real implementers are completely abandoned. Likewise, the other provinces of the country, the Agriculture Research Institute (technologyoriginated-mode) and Agricultural Extension Wing (technology-disseminated-mode) delivering the extension advisory services to the intended growers at province level.

Nonetheless, ill-starred the fruits of these efforts have not been harvested as yet, as compared to the other provinces of the Pakistan. This trend indicates that there is huge gap between technology dissemination and technology adoption processes with the context of weak 
liaised information system of dynamic sectors at province level. Therefore, present study was carried out in order to determine the linear technology transfer stimulation as by using public and private agriculture extension services especially reference of the Balochistan province.

Purpose and objectives: Present research was carried out so as to determine the province agricultural extension system regarding linear technology transfer stimulation in extension services: approaches for the discipline in Balochistan context: Explicitly present study sought to following specific objectives: 1) to examine the limiting factors affecting the agricultural extension activities in the study areas: 2) to explore the mode of action of different approaches as used by the public and private extension services: 3 ) to developed the operational technology transfer stimulation model and conceptual framework for the province agriculture extension system for the policy-makers and stakeholders.

Hypotheses: Based on the research motives, present study was sought to test the following null hypotheses (based on the related review of literature):

- Ho1. There is no significant difference in the perception of extension field staff regarding extension teaching methods.

- Ho2. There is no significant difference in the perception of extension field staff regarding sources of information.

\section{METHODOLOGY}

A descriptive type of research design was used in present study. In descriptive type of research is suitable to obtaining the respondents perception about current condition in the existing nature (Brog, et al., 1989: Trochim 2000; Gall et al., 2007; Cohen et al., 2007). Quetta district was purposively selected, because of all agricultural extension central activities either by public extension or private extension was run through these sectors. A target population as sample size of one hundred (100) Extension Field Staff (EFS) among them seventy (70) form public extension (Agricultural Extension Wing, Agricultural \& Cooperatives Department Government of Balochistan, Quetta) and thirty (30) from private extension (Swat Agro-Chemical (Pvt.), Al-Mehmood Brothers (AMB) and Four Brothers Agric: services in Pakistan) were taken by using the simple random sampling procedure (Ogunjuyigbe et al., 2005; Parrado et al., 2005; Gay \& Mills, 2006). This made a total sample of 100 extension field staff. Both populations were determined by using tables of "selecting sample sizes from given population" (McCall 1980; Wunsch 1986; Fitz-Gibbon \& Morris 1987; Krejcie \& Morgan 1970) at the 0.05 percent error rate. A pretest was conducted using the research instrument on fifteen extension field staff of Quetta district who were not included in the actual sample. A comprehensive research instrument was designed keeping in the view, objective of the present study. Face-to-face communication technique was used for data collection. Cronbach's Alpha program was employed so as to test the reliability of the questionnaire (Ary et al., 1996). The reliability coefficients are indecisive from .87 to .89 , demonstrating that the interval consistency of the questionnaire was excellent (Nunnally 1967; Rothbard \& Edwards 2003 Henneman, 2006; Reynaldo \& Santos, 1999; Henseler et al., 2009; Hair et al., 2012). With regards to, the correctness of scale for measuring the respondents opinions, a 5-point Likert scale was used ranging from ( $1=$ never, $2=$ rarely, $3=$ often, $4=$ almost always, $5=$ always); (Likert 1932; Edwards, 1969). Thus, raw data was coded in tally sheet (Excel) afterward data analysis by using the SPSS version 22.0 for Windows, SPSS Inc, Chicago, IL, USA (SPSS, 2015). Analysis produced sum of rank, mean rank and Wilcoxon W. Nonparametric Statistics i.e. Mann and Whitney's U Test (1947) as appropriate between dual groups was calculated so as to find-out the relationships between variables that have significance differences (Conover, 1980; Gay 1980; Lehmann, 1975; Pallant, 2007; Vaus, 2002). The level of significance was set to $5 \%$ or outcome was accepted as statistically significant when $\mathrm{P}$ was $<0.05$.

\section{RESULTS AND DISCUSSION}

Wilcoxon-Mann-Whitney U Test was directed at 0.05 significant and alpha level, which demonstrating that when $\mathrm{p} \leq 0.05$, there was at least $95 \%$ confidence that dissimilarities between the received opinions snapshot of the dual set of groups (public and private EFS) were statistically different at 0.05 as shown in table-1. 5-point Likert-scaling ranging from (1= stand for never, $2=$ stand for rarely, $3=$ stand for often, $4=$ stand for almost always, $5=$ stand for always) was used a self-measures-report. The relationship of the various types with the MannWhitney U Test exposes that the highly statistical significant differences were found on the one (1) survey item was: group discussion (Mann-Whitney $U=679.000$, $\mathrm{p}<.005)$. 
Three (3) items found statistical significant were: method demonstration (Mann-Whitney $U=810.500$, $\mathrm{p}<.005$ ); group meetings (Mann-Whitney $U=827.000$, $\mathrm{p}<.005$ ) and workshop for farmer (Mann-Whitney U $=832.000, \mathrm{p}<.005)$. Six (6) statements found statistical non-significant were: farm visits (Mann-Whitney U
$=1010.000, \mathrm{p}<.005$ ); home visits (Mann-Whitney U $=850.000, \quad \mathrm{p}<.005)$; result demonstration (MannWhitney $\mathrm{U}=909.000, \mathrm{p}<.005$ ); educational tours (MannWhitney $U=1317.500, \mathrm{p}<.005)$; agricultural exhibitions (Mann-Whitney $\mathrm{U}=837.500, \mathrm{p}<.005$ ) and seminar for farmers (Mann-Whitney U =929.500, p<.005).

Table 1. Perceived score of respondents regarding extension teaching methods.

\begin{tabular}{|c|c|c|c|c|c|c|c|c|}
\hline \multirow{2}{*}{$\begin{array}{l}\text { Extension } \\
\text { method }\end{array}$} & \multicolumn{2}{|c|}{ Public Extension } & \multicolumn{2}{|c|}{ Private Extension } & \multirow{2}{*}{$\begin{array}{c}\text { Mann- } \\
\text { Whitney } \\
\text { U test }\end{array}$} & \multirow{2}{*}{$\begin{array}{c}\text { Wilcoxon } \\
\text { W }\end{array}$} & \multirow[b]{2}{*}{$\mathrm{Z}$} & \multirow{2}{*}{$\begin{array}{c}\text { Asymp Sig } \\
\text { (2 tailed) }\end{array}$} \\
\hline & $\begin{array}{l}\text { Mean } \\
\text { Rank }\end{array}$ & $\begin{array}{l}\text { Sum of } \\
\text { rank }\end{array}$ & $\begin{array}{l}\text { Mean } \\
\text { rank }\end{array}$ & $\begin{array}{l}\text { Sum of } \\
\text { rank }\end{array}$ & & & & \\
\hline Farm visits & 51.07 & 3575.00 & 49.17 & 1475.00 & 1010.000 & 1475.0 & -.355 & $.722 \mathrm{NA}$ \\
\hline Home visits & 53.36 & 3735.00 & 43.83 & 1315.00 & 850.000 & 1315.0 & -1.745 & $.081 \mathrm{NA}$ \\
\hline $\begin{array}{l}\text { Result } \\
\text { demonstration }\end{array}$ & 52.51 & 3676.00 & 45.80 & 1374.00 & 909.000 & 1374.0 & -1.242 & $.214 \mathrm{NA}$ \\
\hline $\begin{array}{l}\text { Method } \\
\text { demonstration }\end{array}$ & 53.92 & 3774.50 & 42.52 & 1275.50 & 810.500 & 1275.5 & -2.074 & $.038^{*}$ \\
\hline Educational tours & 53.32 & 3732.50 & 43.92 & 1317.50 & 852.500 & 1317.5 & -1.708 & $.088 \mathrm{NA}$ \\
\hline Group discussion & 55.80 & 3906.00 & 38.13 & 1144.00 & 679.000 & 1144.0 & -3.732 & $.000^{* *}$ \\
\hline Group meetings & 53.69 & 3758.00 & 43.07 & 1292.00 & 827.000 & 1292.0 & -1.994 & $.046^{*}$ \\
\hline $\begin{array}{l}\text { Agricultural } \\
\text { exhibitions }\end{array}$ & 53.54 & 3747.50 & 43.42 & 1302.50 & 837.500 & 1302.5 & -1.884 & $.060 \mathrm{NA}$ \\
\hline Seminars & 52.22 & 3655.50 & 46.48 & 1394.50 & 929.500 & 1394.5 & -1.147 & $.252 \mathrm{NA}$ \\
\hline Workshops & 53.61 & 43.23 & 3753.0 & 1297.00 & 832.000 & 1297.0 & -2.051 & $.040^{*}$ \\
\hline
\end{tabular}

Scale:1= Never, $2=$ Rarely, $3=$ often, $4=$ Almost always, 5= Always

* Significant ** Highly Significant, at 0.05 alpha level respectively: NA Non-significant.

The Wilcoxon-Mann-Whitney $\mathrm{U}$ Test at $<.5 \%$ significance level were spectacles that there (4) variables were significant between the group perceptions regarding the extension teaching methods. However, discrepancies were by and large attributed by the differences among the dimensions of perceptions.

- Hypothesis 1 (H1): There is no significant difference in the perception of extension field staff regarding extension teaching methods.

To assess this hypothesis, present study measures the extension teaching methods as used by both sectors EFS. The perceptions of EFS in the direction of the ten (10) identified extension teaching methods as used by public and private EFS were measured by using a 5-point Likert-type scale that ranged from " $1=$ never, $2=$ rarely, $3=$ often, 4= almost always, 5= always". The Mann and Whitney's U Test was used to determine if there were any imperative discrepancies occurred between the whole means of group perceptions of extension field staff. EFS gave high preferences to public extension field staff as compared to private extension field staff about extension teaching methods. Significant differences were found 4 out of 10 categories. Based on outcomes, the null hypothesis 1 was rejected in the favor of alternate hypothesis and it was concluded that public EFS was relatively perform proficient services as compared to private EFS. Further, present study outcomes was revealed that farm visits and result demonstration were perceived as effective extension teaching methods as employed by public and private extension field staff. Similar outcomes were reported by Muhammad et al., (1990), Abbas et al., (2003), Ahmad et al., (2005), Oladosu (2006), Siddiqui (2006), Luqman, et al., (2007), Okunade (2007), Khan \& Akram (2012) and Rajper (2013) who found that farm visits were effective extension teaching methods as employed by public and private EFS. A large number of growers perceived that the farm visits was very common and popular among the extension field staff. Because farmers are always involved in the farming practice of their field and most of time they spend time in their field. So, may be these are reasons that the extension agents preferred the farm 
visit due to easily accessible and contact with farmers. Imperative aspect of the present study was to determine the sources of information as used by the public and private extension field staff.

The perceived score was captured to obtain by the research instrument. Data depicted in Table-2 is the illustration regarding sources of information. Ten (10) statements observed to found statistical non-significant at all were; relatives (Mann-Whitney $U=1005.000$, $\mathrm{p}<$.005); neighboring farmers (Mann-Whitney
$\mathrm{U}=900.000, \quad \mathrm{p}<.005) ; \quad$ public EFS (Mann-Whitney $\mathrm{U}=934.000, \mathrm{p}<.005)$; private EFS (Mann-Whitney $\mathrm{U}=1025.500, \quad \mathrm{p}<.005) ; \quad$ dealers $\quad$ (Mann-Whitney $\mathrm{U}=1030.000, \mathrm{p}<.005)$; printed material (Mann-Whitney $\mathrm{U}=1013.000, \quad \mathrm{p}<.005$ ); internet (Mann-Whitney $\mathrm{U}=1043.500, \mathrm{p}<.005$ ); mobile phone (Mann-Whitney $\mathrm{U}=971.000, \quad \mathrm{p}<.005) ; \quad$ campaign $\quad$ (Mann-Whitney $\mathrm{U}=953.500, \quad \mathrm{p}<.005$ ) and TV (Mann-Whitney $\mathrm{U}=1004.500, \mathrm{p}<.005$ ). However, significant differences were found 10 out of 10 categories at $p<.005$ ).

Table 2. Perceived score of respondents regarding sources of information.

\begin{tabular}{|c|c|c|c|c|c|c|c|c|}
\hline \multirow[b]{2}{*}{ Information Sources } & \multicolumn{2}{|c|}{ Public Extension } & \multicolumn{2}{|c|}{ Private Extension } & \multirow{2}{*}{$\begin{array}{c}\text { Mann- } \\
\text { Whitney } \\
\text { U test }\end{array}$} & \multirow{2}{*}{$\begin{array}{c}\text { Wilcoxon } \\
\text { W }\end{array}$} & \multirow[b]{2}{*}{$\mathrm{Z}$} & \multirow{2}{*}{$\begin{array}{c}\text { Asymp Sig (2 } \\
\text { tailed) }\end{array}$} \\
\hline & $\begin{array}{c}\text { Mean } \\
\text { rank }\end{array}$ & $\begin{array}{c}\text { Sum of } \\
\text { rank }\end{array}$ & $\begin{array}{l}\text { Mean } \\
\text { rank }\end{array}$ & $\begin{array}{c}\text { Sum of } \\
\text { rank }\end{array}$ & & & & \\
\hline Relatives & 51.14 & 3580.0 & 49.00 & 1470.00 & 1005.00 & 1470.000 & -.380 & $.704 \mathrm{NA}$ \\
\hline Neighboring farmers & 52.64 & 3685.0 & 45.50 & 1365.00 & 900.000 & 1365.000 & -1.217 & $.224 \mathrm{NA}$ \\
\hline Public EFS & 48.84 & 3419.0 & 54.37 & 1631.00 & 934.000 & 3419.000 & -1.006 & $.315 \mathrm{NA}$ \\
\hline Private EFS & 50.15 & 3510.5 & 51.32 & 1539.50 & 1025.50 & 3510.500 & -.199 & $.842 \mathrm{NA}$ \\
\hline Dealers & 50.21 & 3515.0 & 51.17 & 1535.00 & 1030.00 & 3515.000 & -.173 & $.863 \mathrm{NA}$ \\
\hline Printed material & 51.03 & 3572.0 & 49.27 & 1478.00 & 1013.00 & 1478.000 & -.310 & $.757 \mathrm{NA}$ \\
\hline Internet & 50.41 & 3528.5 & 50.72 & 1521.50 & 1043.50 & 3528.500 & -.053 & $.958 \mathrm{NA}$ \\
\hline Mobile phone & 49.37 & 3456.0 & 53.13 & 1594.00 & 971.000 & 3456.000 & -.624 & $.532 \mathrm{NA}$ \\
\hline Campaign & 49.12 & 3438.5 & 53.72 & 1611.50 & 953.500 & 3438.500 & -.776 & $.438 \mathrm{NA}$ \\
\hline TV & 51.15 & 3580.5 & 48.98 & 1469.50 & 1004.50 & 1469.500 & -.359 & $.720 \mathrm{NA}$ \\
\hline
\end{tabular}

Scale:1= Never, 2= Rarely, $3=$ often, $4=$ Almost always, $5=$ Always

* Significant ${ }^{* *}$ Highly Significant, at 0.05 alpha level respectively: NA Non-significant.

- Hypothesis 2 (H2): There is no significant difference in the perception of extension field staff regarding sources of information.

In testing this hypothesis, present study was acknowledged numerous sources of information. Fivepoint Likert scale was rummage-sale where 1 stands for "never", 2 for "rarely", 3 stands for "often", 4 for "almost always", and 5 stands for "always". The null hypothesis exhibited noteworthy dissimilarities between the public and private extension field staff acuities. Therefore, the HO2 was accepted in the favour of alternate hypothesis in 10 out of 10 categories about sources of information. Hence, it was concluded that similar trends were observed of both sectors extension field staff perceptions. Farmer respondents were also asked to identify the main sources of information they utilize. The results revealed that the neighbouring farmers were the main source of information as perceived by the respondents. These finding are in line with the findings of Muhammad and Garforth (1999), Irfan et al. (2006),
Siddiqui (2006), Taj et al. (2009), Adebiyi et al. (2011), Bahalkani, (2013), Ali et al. (2014) and Fatima et al. (2014) who reported that the neighbouring farmers served as main sources of agricultural information. This might be due to the fact that neighbouring farmers are easily in contact with each other due to short distance between their houses, same background, origin, tradition and culture. Therefore, they easily share their views regarding domestic problems and exchange their views regarding the farming issues. Neighbouring farmers learning broadly from one another provides an argument about traditional farming methods that views farmers as passive receptions of knowledge and skills. Effective transfer of technology plays imperative steering role in development process (Youndt et al., 1996; Ferris et al., 1999). Frequent variations in technology with the increasing significance of knowledge-based organizations, change development process into a progressively more important facet of human resource development. Afterward, working-out 
with the term of development programs is planned whereas using innovation in diverse approaches (Niazi, 2011). Present effective linear technology transfer core value streamline to stimulus on entirely human resource management capacities and dynamics. The transfer of technology operative system or process here intact stressed upon the socially dimension, economically worthwhile, culturally acceptable and politically rigorous themes. However, HRD segment had reflected been the cascading effects on entire required development loop and progress with the term of enhancement tools appliance as shown in figure-1.

In order to stimulate the agriculture extension system in operative fashion present systematic stimulation approaches as matrix was developed as shown in figure2. By nature, public extension services at province level had top-down style, elaborate bureaucratic style, linear and settled based on hierarchical pattern utterly. The route of decision-making process within system was apprehended, possessed and decided by the upper provincial bureaucracy as a result, repentance the marginal farming community needs and requirements. Cohen and Lemma (2011) stated that the method of extension service provision relies on top-down, style with the term of accountability mostly flowing upward. On the other hands, private extension services mostly used as holistic and prompt approaches; to concentrate the large land holding size growers due to their profitoriented motives. At this instant, question was arising how to make the agriculture extension more effective in order to fulfill the farming community present day prerequisite necessities. So contemporary stimulation approaches had highlighted the helpful and harmful aspects and their relative contribution at matrix shape. Systematic stimulation matrix of technology transfer, which highlights the public and private extension services with upward arrows denotes required factors i.e. helpful aspects while, in this connection both sectors with horizontal arrows as lower case shows un-required factors i.e. harmful aspects. It is proposed that existing systematic stimulation approaches can be cooperative in public-private extension services about activation dimension if compact efforts are made to minimize the harmful aspect using its helpful aspect and availing its prospects. Perceptibly, both public and private extension made dynamic mode of linkages and joint-venture programs for the betterment of deprived farming communities of the province.

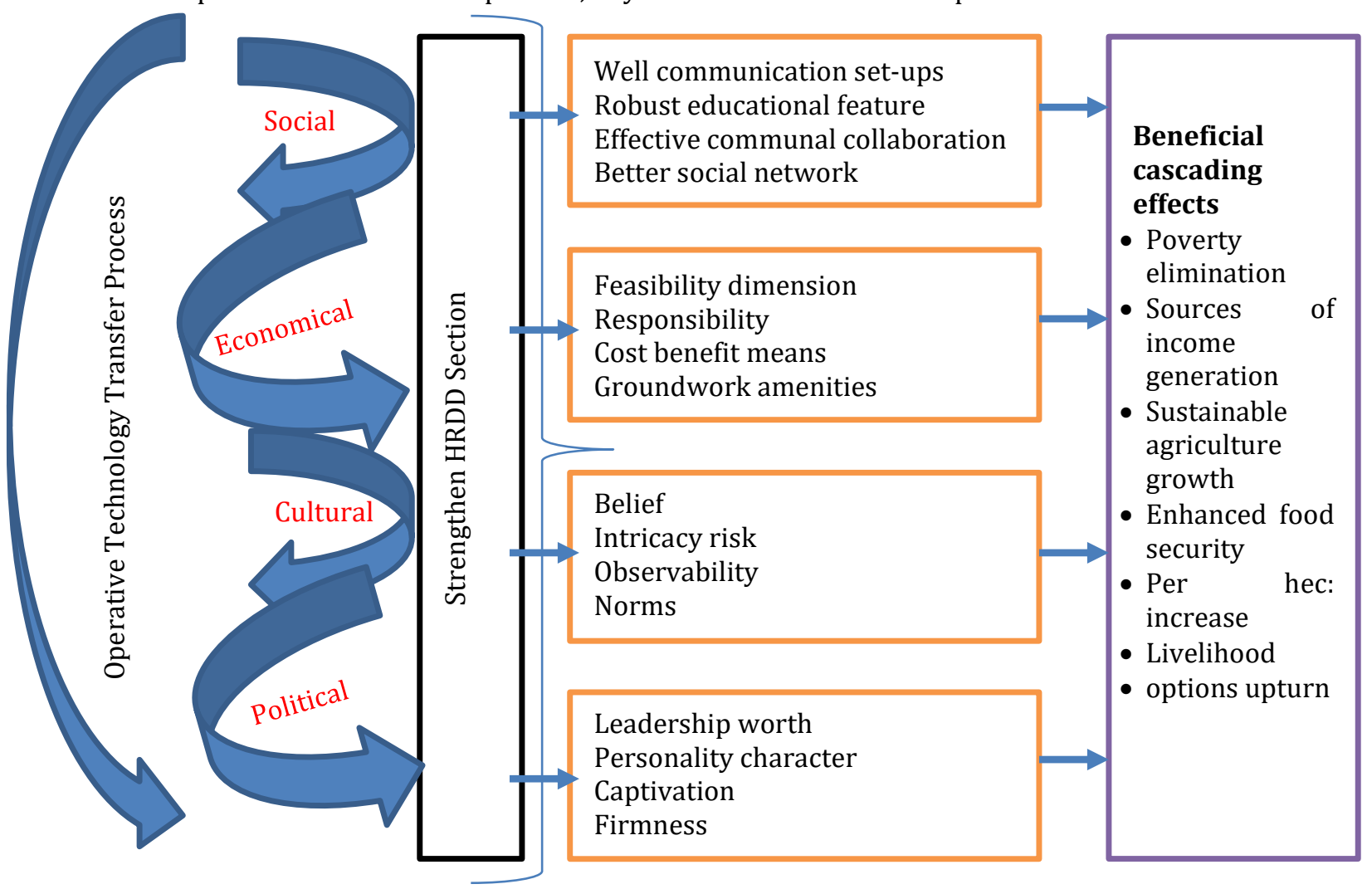

Figure 1. Effective linear technology transfer stimulation model. 
The limiting factors were the notable handicap direction within any system. Present snags not only discontinuity the development process within system but also reflects the negative impact on the socio-economic condition of the farmers. The figure-3 depicted that the leading barriers contained by province agriculture extension system. Province level EFS have several duties with restricted budget and time constraints/limitations.

They provided technical information not only on fruits, vegees and other crops, to the farmers but also propagate the agricultural ideals such as organic farming to the intended recipients.

Conceptual framework: Based on the achieved outcomes, findings and limiting factors from present study, below was the conceptual framework that would be worthwhile useful, informative, beneficial and fruitful for the province agriculture extension system and develop the dissemination or information system of agricultural technologies transfer in Balochistan through the state-of-the-art trainings, and programs (Figure 4).

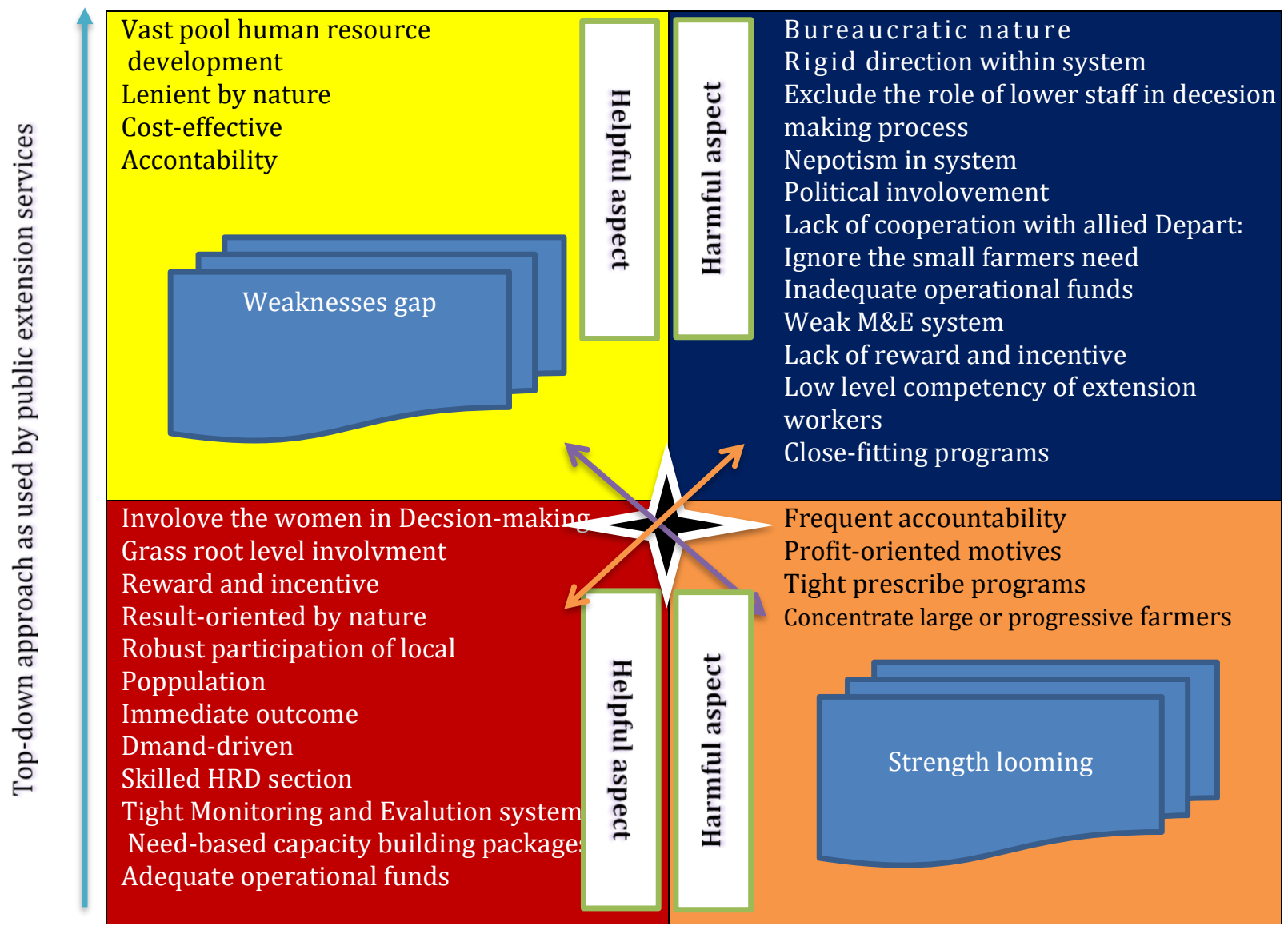

Figure 2. Participatory approach as used by private extension services.

Every dynamic learning process were either explicitly or implicitly ground to judge on conceptual framework, particular, in social sciences and educational circles measurement hinge on of conceptual framework or expected variables of interest. As identified in the present conceptual framework of this research, respondent's perceptions are shaped from side to side 'individuals' experience, know-how and capacity building foci (Leeper, 1935). This scenario coined to point toward that there is a dare need for farmers to focus on the system, as most of them comprehend that agriculture extension services are worthwhile. Therefore, firm efforts should be made in order to improve the agriculture extension services at province level. Results of the present study may perhaps play an inspiring role in order to facilitating to improve the efficiency of the province agriculture extension services as used by public and private extension services, as it may also be used for strategic planning, for the execution of agriculture extension services. Hence, the farmers' perceptions have an influence to effect on participation with the term of adoption of latest agriculture technologies. 


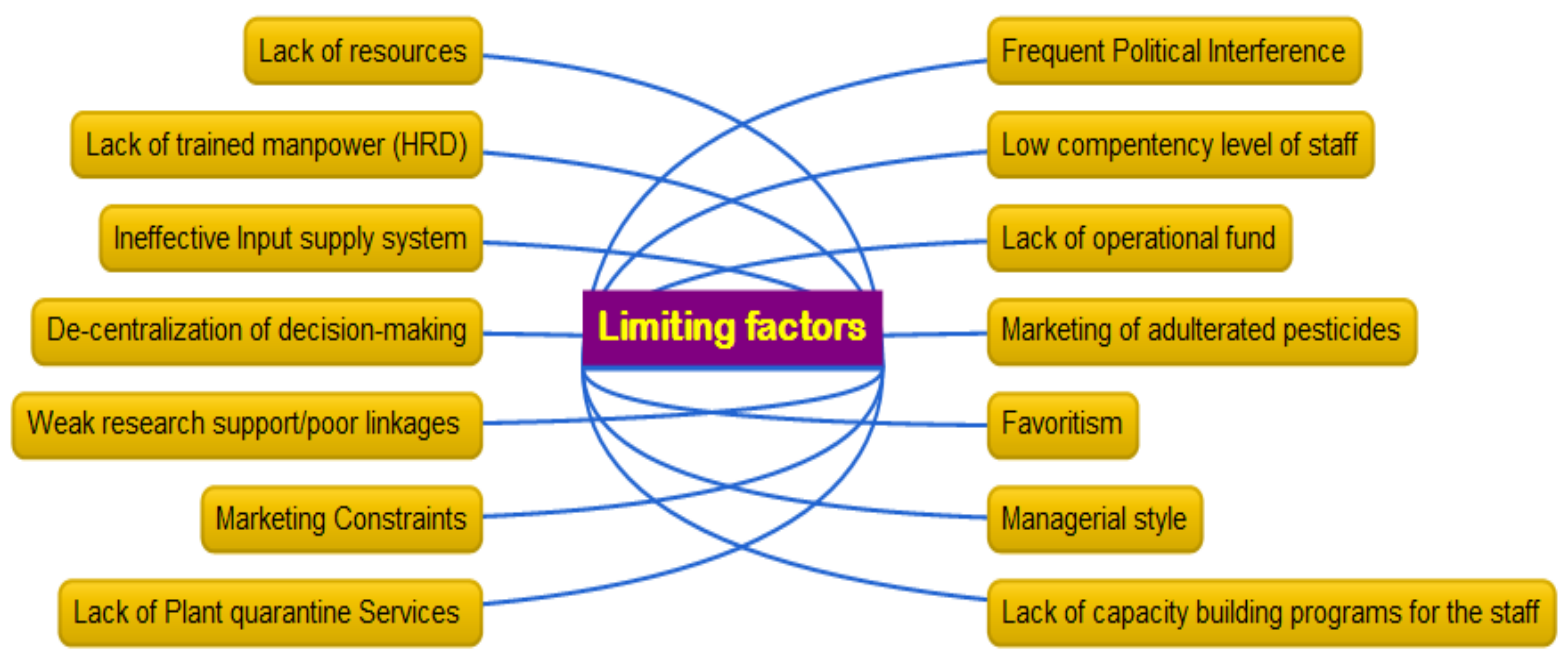

Figure 3. Perceived limiting factor within extension services.

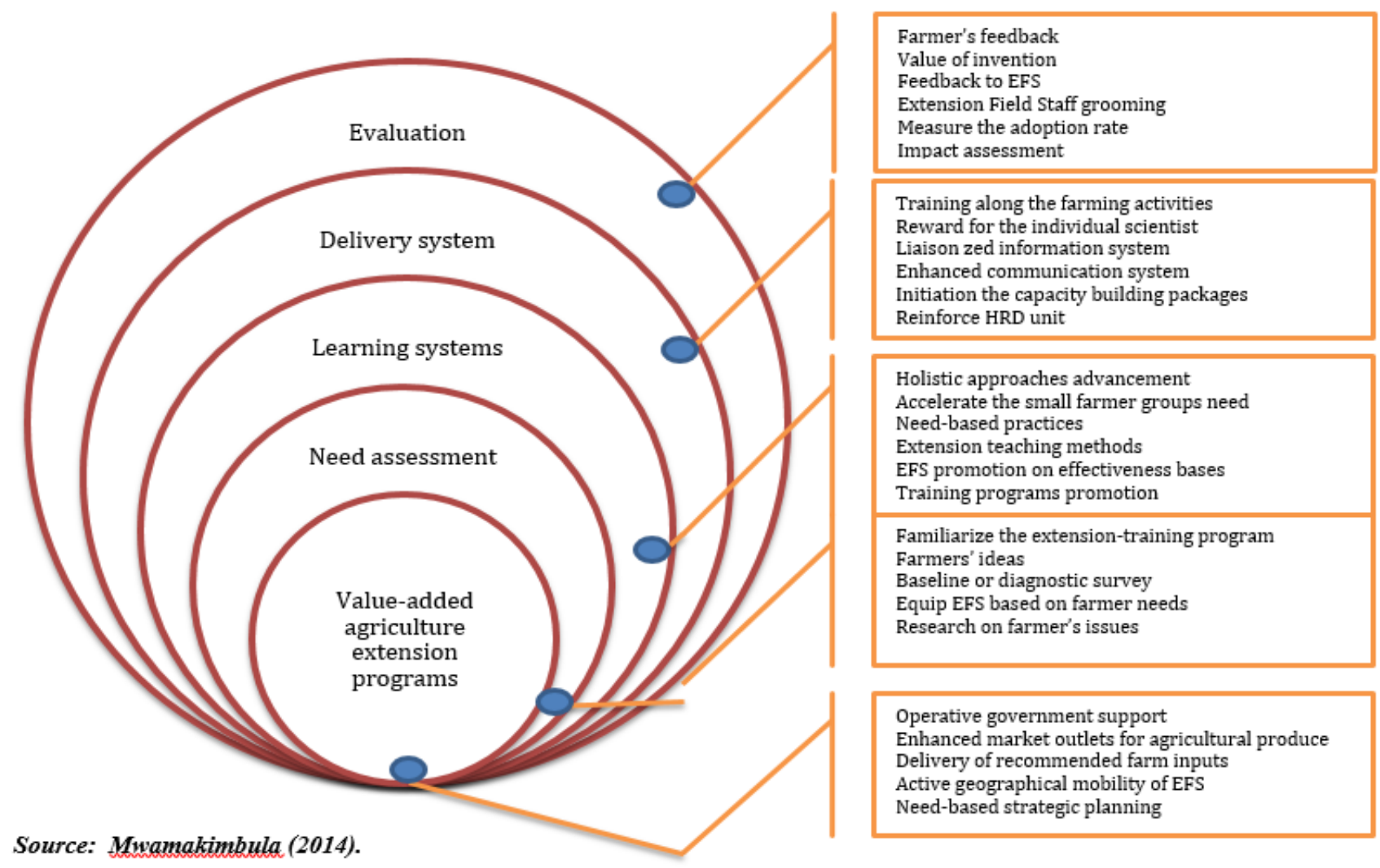

Figure 4. Conceptual framework as theoretical underpinnings based on implication.

\section{CONCLUSION AND RECOMMENDATIONS}

Province agriculture system slowly and gradually has further low-down incredible discrepancies in this regard; traditional method of farming is solely no more economical. Keep in view above facts therefore, there is a dare need to improve the province agriculture system so as to boast up the farmers socio-economic condition. Following recommendations put forward or are made for vertical and horizontal enlargements in the existing extension services as reinforcement-mode in the 
Balochistan province. Farmers are the last hierarchy aspects of the development process, it is therefore suggested that present agriculture information section should be re-strengthen and re-structured into dynamic information system with the term of exchange of view, improving quality, effective linkages and distribution system in order to bridging the gap between potential and actual farm sequential productivity. Financial incentive should be provided to individual experts/scientists so as to encourage their research capacity at all level. Rather than top-down approaches towards the marginal farming communities the bottomup approaches should be adopted so as to solve the farmer's problem and farmers should be involved in the decision-making process/ preliminary phase of planning. Government should execute the effective monitoring and evaluation (M\&E) system (s) so that identifying the flaws and deficiencies within agriculture extension services. The information section should be liaised in effective ways and keeping in view farmers' needs at all stages. In-service capacity building programs on mandatory bases for the staff should be arranged so as to familiarize them with the applied complications of the field. Dissemination of improved and useful information's to the farmers are the vivid encouragement tools and energizer trends about crop production dynamics in this regard, it is therefore suggested that, extension teaching methods (individuals and groups contact methods) such as demonstration plots, farm visits, home visits, uses audio-visual media, seminar, campaigns, workshops, trainings should be arranged at districts and province level so that activate the entire agricultural extension system. Active crop maximization approach should be implemented in preliminary stages in order to increases the income generations and livelihood options of the farmers.

\section{REFERENCES}

Abbas, M. S. Muhammad, N. Iftikhar \& Sheikh, A. D. (2003). Farmer-extension interaction and the dissemination of recommended sugarcane production technologies in the Central Punjab (Pakistan). International Journal of Agriculture \&. Biology, 5(2),134-137.

Adebiyi, S. E. O. Uwagboe, E. A. Agbongiarhuoyi, I. Ndagi \& Aigbekaen, E. O. (2011). Assessment of agronomic practices among Kola farmers in Osun State, Nigeria: World Journal of Agriculture Sciences, 7(4), 400-403.
Ahmad, M. A. Tanvir, S. K. Ahmad, \& H. Amer. (2005). Perceived credibility of private sector in introducing Integrated Pest Management (IPM) technologies with special reference to sugarcane crop in district Faisalabad. Pakistan Journal of Entomology, 27(2), 53-56.

Ali, M. Saddiqui, B. N. \& Naeem, K. (2014). Attitude of small farmers toward the use of ICTs to ensure food security in district Rawalpindi. A paper presented at the International Conference "Emerging Horizons of Agricultural Extension for Sustainable Rural Development", organized by University of Agriculture Faisalabad, Pakistan, on 27-28 February, 2014.

Ary, D. Jacobs L. C. \& Razaveieh, A. (1996). Introduction to Research Education.5th ed. New York: Holt, Rinehart and Winston, Inc.

Bahalkani, N. A. (2013). Study of the diffusion and adoption of production practices of hybrid rice in Taluka Tangwani, District Kashmore, Sindh. M. Sc. Agric. Ext., Sindh Agric. Univ., Tandojam Sindh, Pakistan.

Brog, W. R. \& Gall, M. D. (1989). Educational Research. (5th ed.) Longman. New York.USA.

Cohen, L. Manion, L. \& Morrison, K. (2007). Research Methods in Education 6th ed. London: Routledge.

Cohen, M. J. \& Lemma, M. (2011). Agricultural Extension Services \& Gender Equality: An Institutional Analysis of Fouroormation Districts in Ethiopia. IFPRI Discussion Paper No. 01094. Washington, D. C.

Conover, W. J. (1980). Practical nonparametric statistics (ed 2). New York, NY, John Wiley \& Sons Inc. Pp 216-228.

Edwards, A. L. (1969). Techniques of Attitude Scale Construction, Vakils and Simon Pvt. Ltd., Bombay.

Fatima, I. Siddiqui, B. N. Ali, M. \& Naseem, K. (2014). Selfperceived role of rural youth in ensuring food security in tehsil Rawalpindi, Pakistan. A paper presented at the International Conference "Emerging Horizons of Agricultural Extension for Sustainable Rural Development", organized by University of Agriculture Faisalabad, Pakistan, on 27-28 February, 2014

Ferris, G. R. Hochwarter, W. A. Buckley, M. R. HarrellCook, G. \& Fink, D. D. (1999). Human Resources Management: Some New Directions,' Journal of Management, 25 (3), 385-415. 
Fitzgibbon, C.T. \& Morris, L. L. (1987). How to Design a Program Evaluation. Newbury Park, CA: Sage.

Gall, M. D. Gall, J. P. \& Borg, W. R. (2007). Educational research: An introduction (8th Ed.). New York: Longman.

Gay, L. R. (1980). Educational evaluation and measurement: Competencies for analysis and aapplication. Columbus, OH. Charles E Merrill Pulishing Co. Pp 104-137.

Gay, L. R. \& Mills, G. E. (2006). Educational Research: Competencies for Analysis and Applications5th ed. Upper Saddle River, N.J.: Merrill/Prentice Hall.

GoP, (2016). Pakistan Economic Survey 2015-16. Agriculture Chapter-II, Economic Adviser's Wing, Finance Division, Government of Pakistan, Islamabad., pp. 23-41.

Hair, J. F., Sarstedt, M., Pieper, T. \& Ringle, C. M. (2012). The Use of Partial Least Squares Structural Equation Modeling in Strategic Management Research: A Review of Past Practices and Recommendations for Future Applications. Long Range Planning, 45, 320-340.

Henneman, R. A. (2006). Cronbach's alpha reliability analysis with SAS. University of California.

Henseler, J. Ringle, C. M. \& Sinkovics, R. R. (2009). The Use of Partial Least Squares Path Modeling in International Marketing. Advances in International Marketing, 20, 277-319.

Irfan, M. S. Muhammad, G. A. Khan \& Muhammad, A. (2006). Role of mass media in the dissemination of agricultural technologies among farmers: International Journal of Agriculture and Biology, 8(3), 417-419.

Javed, Z. H. Farooq M. \& Ali, H. (2010). Technology transfer and agricultural growth in Pakistan. Pakistan Journal of Agriculture Sciences, 47(1), 82-87.

Khan, A. \& Akram, M. (2012). Farmers' perception of extension methods used by Extension Personnel for dissemination of new agricultural technologies in Khyber Pakhtunkhwa, Pakistan. Sarhad Journal of Agriculture, 28(3), 511-520.

Krejcie, R. V. \& Morgan, D. W. (1970). Determining sample size for research activities: Educational and Psychological Measurement. Sage Publication, Inc.

Leeper, R. (1935). A study of a neglected portion of the field of learning: The development of sensory organization. Genetic Psychology, 46, 41-75.

Lehmann, E. L. (1975). Nonparametric Statistical Methods Based on Ranks. San Francisco, CA: Holden-Day.

Likert, R. (1932). A technique for the measurement of attitudes: Archives of psychology. 22(140), 1-55.

Luqman, M. A. Kafeel, Y. Muhammad, A. \& Zafar, I. K. (2007). Effectiveness of decentralized agricultural extension system (a case study of Pakistan): African crop science conference proceedings, (8), 1465-1472.

Mann, H. B. \& Whitney, D. R. (1947). On a Test of Whether one of Two Random Variables is Stochastically Larger than the other. The Annals of Mathematical Statistics, 18(1), 50-60.

McCall, C. (1980). Sampling and statistics handbook for research in education. National Education Association, USA.

Mengal, A. A. Mallah, M. U. Mirani, Z. A. \& Siddiqui, B. N. (2012). An analysis of public and private agricultural extension Services in Baluchistan, Pakistan. Pakistan Journal of Agriculture Research, 25(4), 10-21.

Mengal, A. A. Mirani, Z. A. \& Magsi, H. (2014). Historical overview of agricultural extension services in Pakistan. The Macro-theme Review 3(8), 23-36.

Muhammad, C., S. M. Asghar, M. C. Khalid, \& A. K. Saeed. (1990). An evaluation of extension teaching methods/media used for the adoption of recommended water management practices by farmers. Pakistan Journal of Agriculture Sciences.,27(2), 102.

Muhammad, S. \& Garforth. C. (1999). Farmers' information source and their relative effectiveness. International Journal of Agriculture and Biology, 4(1), 222-226.

Mwamakimbula, A. M. (2014). Assessment of the factors impacting agricultural extension training programs in Tanzania: a descriptive study. Master of Science. Thesis, Univ. Lowa State., USA (Unpublished dissertation).

Niazi, A. S. (2011). Training and development strategy and its role in organizational performance: Journal of Public Administration and Governance, 1 (2),42-57.

Nunnally, J. C. (1967). Psychometric theory. New York: McGraw-Hill.

Ogunjuyigbe. P. O. Akinlo, A. \& Ebigbola, J. A. (2005). 
Violence Against Women: An examination of men's attitudes and perceptions about wife beating and contraceptive use. Journal of Asian and African Studies, 40(3), 219-229.

Okunade, E.O.(2007). Effectiveness of extension teaching methods in acquiring knowledge, skill \& attitude by women farmers in Osun State. Journal of Applied Sciences and Research, 3(4), 282-286.

Oladosu, I. O. (2006). Implications of farmers' attitude towards extension agents on future extension programme planning in Oyo State of Nigeria. Journal of Social Sciences, 12(2), 115-118.

Pallant, J. (2007). SPSS Survival Manual: A Step-by-Step Guide to Data Analysis using SPSS Version 15. New York: McGraw Hill.

Parrado, E. A. Quiston, C. M. C. \& Flippen, C. A. (2005). Integrating community collaboration and quantitative methods for the study of gender and HIV risks among Hispanic migrants. Sociological Methods \& Research, 34(2), 204-239. Sage Publications.

Qamar, M. K. (2005). Modernizing National Agricultural Extension Systems: a Practical Guide for PolicyMakers of Developing Countries. FAO, Rome, Italy.

Rajper, M. A. (2013). A comparative study of public \& private extension services for wheat in disrtict Naushahro Feroze, Sindh. M.Sc. Thesis, Agriculture Extension, Sindh, Agriculture University, Tandojam Sindh, Pakistan.

Reynaldo, J. \& Santos, A. (1999). Cronbach's Alpha: A tool for assessing the reliability of scales. J. Extens.

Rothbard, N. P. \& Edwards, J. R. (2003). Investment in work and family roles: A test of identity and utilitarian motives. Personnel Psychology, (56), 699-729.

Siddiqui, B. N. (2006). Analysis of communication interventions of extension field staff in apple growing areas of Balochistan (Pakistan). Ph. D. Agriculture Extension, Thesis, University of Agriculture, Faisalabad, Pakistan (Unpublished dissertation).

Spector, P. E. (1992). Summated Rating Scale Construction-An Introduction. Sage Publication, Newburry Park.

SPSS, Inc. (2015). Statistical Package for the Social Sciences (Version 23) [computer software]. New York, USA: IBM Corporation.

Taj, S. Nadeem, A. Muhammad, S. \& Athar, M. (2009). Diffusion process of innovation learning system in the rice wheat production system of the Punjab: Pakistan Journal of Agriculture Sciences, 46(2), 130-137.

Trochim, W. M. (2000). The Research Methods Knowledge Base, 2nd Edition. Atomic Dog Publishing, Cincinnati, $\mathrm{OH}$.

Vaus, D. D. (2002). Analyzing Social Science Data. London: Sage Publication.

Wunsch, D. R. (1986). Forum feature: Action research in business education. Business Education Forum. 5,31-34.

Youndt, M. A. Snell, S. A. Dean, J. W. Jr, \& Lepak, D. P. (1996). Human Resource Management, Manufacturing Strategy, \& Firm Performance. The Academy of Management Journal, 39, 836-841. 